\title{
Mortality and incidence of tumours among ferrochromium workers
}

\author{
G AXELSSON, ${ }^{1}$ R RYLANDER, ${ }^{1}$ AND A SCHMIDT ${ }^{2}$ \\ From the Department of Environmental Hygiene, ${ }^{1}$ University of Gothenburg, Gothenburg, and the \\ Medical Division, ${ }^{2}$ AB Ferrolegeringar, Trollhättan, Sweden
}

\begin{abstract}
An investigation was carried out to determine the cause of death and the incidence of tumours among 1932 workers in a ferrochromium plant in Sweden. The workers had been exposed mainly to metallic and trivalent chromium $\left(\mathrm{Cr}^{3+}\right)$; hexavalent chromium $\left(\mathrm{Cr}^{6+}\right)$ was also present in certain working operations. The population was defined as all men employed at the plant for at least one year during 1930-75, and were classified according to their occupation within the industry. The causes of death were initially obtained from parish registers. For deaths occurring between 1951 and 1975, death certificates were collected from the National Central Bureau of Statistics. Data on the incidence of cancer during 1958-75 were obtained from the Swedish National Cancer Registry. Expected death rates and incidence of tumours were calculated, based on the rates for the county in which the factory was situated. The total number of deaths from tumours was less than expected (69 versus 76.7). Five cases of respiratory cancer were found, against an expected 7-2. Among maintenance workers, an increased death rate from all tumours and an increased number of respiratory tumours were found. Two of the latter were mesotheliomas and could be connected with asbestos exposure. No increase was found for respiratory tumours among the heavily exposed workers at the arc-furnaces; one case of mesothelioma was found in this group.
\end{abstract}

A relation between exposure to hexavalent chromium $\left(\mathrm{Cr}^{6+}\right)$ and cancer has been shown in studies on workers in chromate industries ${ }^{1}$; but few investigations have been undertaken to determine the risk of developing malignant tumours after exposure to metallic and trivalent chromium $\left(\mathrm{Cr}^{0}\right.$ or $\left.\mathrm{Cr}^{3+}\right)$. Mancuso (at the International Conference on Heavy Metals in the Environment, Toronto, 27-31 October 1975 (unpublished observations)), suggested that $\mathrm{Cr}^{3+}$ could cause the development of lung cancer, but his conclusion was drawn from studies using a population in which the major exposure had probably been to $\mathrm{Cr}^{6+}$.

Exposure to $\mathrm{Cr}^{0}$ and $\mathrm{Cr}^{3+}$ occurs in the ferrochromium industry. In the processes used chromite ore, quartz, lime, and coke are mixed in arc-furnaces and ferrochromium alloys are produced by reduction; $\mathrm{Cr}^{6+}$ is present at some stages of the production.

The study was supported by funds from the Swedish Work Environment Fund and the Swedish Cancer Society.

Received 24 May 1979

Accepted 2 October 1979
To investigate whether exposure in the ferrochromium industry could be associated with an increased risk of developing tumours, especially lung cancer, a study was made among workers in a ferrochromium plant in Sweden (Ferrolegeringar Trollhätteverken AB, Trollhättan). A cohort of employees was examined with regard to cause of death and incidence of cancer.

\section{Material and methods}

The subjects in the study were defined as all men employed for at least one year during the period 1 January 1930 to 31 December 1975 . The plant had retained all employment cards on individual workers since 1913. For each employee, information on date of birth and dates of first and last employment was collected. Information on year of death was obtained from parish registers. Information on perforations of nasal septa was obtained by reviewing files from employees' medical examinations.

The different working sites within the industry were classified into four groups with regard to exposure to $\mathrm{Cr}^{3+}$ and $\mathrm{Cr}^{6+}$. Approximate calculations were 
made based on recent measurements and discussions with retired workers and foremen employed in the 1930s.

Asbestos-containing materials, such as textiles, plates, and asbestos-isolated tubes, had been used in the plant. During 1931-40 the mean consumption was $2100 \mathrm{~kg} /$ year and during $1941-50$ about 650 $\mathrm{kg} /$ year.

Individuals in the cohort were classified according to their working site within the industry, using information on register cards for each individual. Several of the employed had worked at more than one site. Generally, the classification was made against the background of the working site where the person had worked the longest time. An exception to this classification model was, however, made for 37 workers exposed periodically to both extremely high levels and extremely low levels. If the period of high exposure constituted one-third or more of the total employment time the employee was assigned to the high-exposure group. Data on causes of death were obtained from the National Central Bureau of Statistics and were coded using International Statistical Classification of Diseases, Injuries and Causes of Death, 8th revision. As the Bureau altered its classification of causes of death on 1 January 1951, the cohort for this analysis was limited to those who were still alive on that date (1876 workers). Corrections were made for changes in classification made during 1951-75. Information on causes of death was also obtained from the parish death registers for everyone, including those who died between 1931 and 1950 (56).

The causes of death between 1951 and 1975 in the cohort were compared with causes of death in the male population in the county in which the industry was situated. ${ }^{3}$ The cohort was stratified in five-year age groups $(15-19,20-4,25-9$, etc). The expected mortality was calculated by multiplying the number of people in each age group in the cohort with the age-specific mortality for each of the years 1951 to 1975. For those who had moved out of the county the expected mortality was calculated based on national statistics from the year when they moved.

For the study of the incidence of cancer, a manual search was made at the Cancer Registry at the National Board of Health and Welfare. All employees who were alive on 1 January 1958 (1823) were checked against the register for the period 1958-75. The expected number of cases of cancer was calculated using the same methods as in the investigation on causes of death, but a 15-year latency period from the onset of employment was included. The national and county incidence data were obtained from the annual publications of the Cancer Registry (1958-72). ${ }^{4}$ As no data for $1973-5$ were available, the county incidence for 1972 was used for these three years.

For each comparison of expected and observed values two-sided $p$-values were calculated using the Poisson distribution. Values less than 0.05 are given in the tables.

\section{Results}

\section{EXPOSURE}

Table 1 shows the estimated exposures at the various working sites. Exposure to $\mathrm{Cr}^{3+}$ was highest for workers at arc-furnaces, including maintenance personnel, and for those working with metal grinding and sample preparation. The highest exposure to $\mathrm{Cr}^{6+}$ was found in arc-furnace operations. Exposure to $\mathrm{Cr}^{6+}$ also occurred in a chromate reduction process in the chromium alum production that operated from 1950 to 1956 . No exposure values could be estimated for that process.

Table 1 Working sites and estimated levels of exposure $\left(\mathrm{mg} / \mathrm{m}^{3}\right)$

\begin{tabular}{lll}
\hline & $\mathrm{Cr}^{0}+\mathrm{Cr}^{3+}$ & $\mathrm{Cr}^{\mathrm{6}+}$ \\
\hline Arc-furnaces & $2 \cdot 5$ & $\mathbf{0} 25$ \\
Transport, metal grinder, sampling & $\mathbf{0 \cdot 5 - 2 \cdot 5}$ & $\mathbf{0 \cdot 0 1 - 0 \cdot 0 5}$ \\
Maintenance & $2 \cdot 5$ & $0 \cdot 05$ \\
Office, storage area & 0 & 0 \\
\hline
\end{tabular}

PERFORATIONS OF NASAL SEPTUM

Clinical observations among the employed during the last three years showed a perforation of the nasal septum in three workers. One had been employed from 1928 to 1978 and had worked with the chromium alum production. The second was employed from 1942 to 1956 and worked with the same process for the whole period. The third started in 1956 and for seven years worked close to one of the ovens where calcium and chromium were roasted. These processes were not in use when the present investigation was undertaken.

A few years before the investigation, changes on the nasal epithelium at the characteristic site of perforations were observed among some of the workers. The changes appeared as round etchings of $5-8 \mathrm{~mm}$ in diameter, with coagulated epithelium on both sides of the septum. These acute changes usually disappeared over the weekend. After the introduction of breathing filters the effect disappeared.

\section{MORTALITY}

All but one of the defined population could be traced. Of the 1876 who were alive on 1 January 
Table 2 Employees at different working sites related to year of entry into employment and year of birth

\begin{tabular}{|c|c|c|c|c|}
\hline & Arc-furnaces & $\begin{array}{l}\text { Transport, metal } \\
\text { grinder, sampling }\end{array}$ & Maintenance & Office, storage area \\
\hline \multicolumn{5}{|c|}{$\begin{array}{l}\text { Year of entry into } \\
\text { employment }\end{array}$} \\
\hline-1930 & 90 & 62 & 42 & 24 \\
\hline $1931-40$ & 68 & 96 & 35 & 37 \\
\hline $1941-50$ & 117 & 133 & 66 & 59 \\
\hline $1951-60$ & 177 & 129 & 64 & 57 \\
\hline $1961-70$ & 131 & 81 & 78 & 118 \\
\hline 1971- & 58 & 57 & 41 & 56 \\
\hline \multicolumn{5}{|l|}{ Year of birth } \\
\hline-1890 & 48 & 33 & 21 & 6 \\
\hline $1891-1900$ & 66 & 64 & 35 & 22 \\
\hline $1901-10$ & 105 & 101 & 43 & 54 \\
\hline $1911-20$ & 88 & 116 & 49 & 57 \\
\hline $1921-30$ & 127 & 91 & 56 & 66 \\
\hline $1931-40$ & 111 & 69 & 43 & 58 \\
\hline 1941- & 96 & 84 & 79 & 88 \\
\hline
\end{tabular}

1951, 380 died before the end of 1975. Table 2 shows the cohort with relation to year of entry into employment, year of birth, and working sites.

The cause of death according to death certificates in the cohort with relation to working site is shown in table 3 . The total death rate was close to that expected, but the number of deaths due to accidents, poisoning, and violence was 48 compared with an expected of 36 . Of these deaths, 13 were known suicides and 12 drownings. Two of the accidental deaths were related to the working place.

The total number of deaths from tumours was slightly lower than expected, and the number of tumours in respiratory organs was less than expected, independent of the duration of employment (tables 4 and 5). In tumours with "other locations" the two largest groups were tumours of the kidney and liver. None of the slight differences noted between the cohort and the county population was statistically significant.

In table 6 deaths from tumours are related to the working site and to the length of employment. For highly exposed workers at the furnaces the observed number of deaths was not higher than expected, either totally or for any length of employment. Among maintenance workers, the number of deaths from tumours for employment times of one to four years and five to 14 years was higher than expected. The difference between the observed and expected value for the period up to 14 years was statistically significant $(\mathrm{p}=0.03)$.

Table 3 Number of deaths from various causes for different work places during 1951-75. Numbers of men and man-years are calculated from 1951

\begin{tabular}{|c|c|c|c|c|c|c|c|c|c|c|c|}
\hline & \multirow[b]{2}{*}{$!$} & \multicolumn{2}{|c|}{ Arc-furnaces } & \multicolumn{2}{|c|}{$\begin{array}{l}\text { Transport, metal } \\
\text { grinder, sampling }\end{array}$} & \multicolumn{2}{|c|}{ Maintenance } & \multicolumn{2}{|c|}{$\begin{array}{l}\text { Office, storage } \\
\text { area, other } \\
\text { non-chromium } \\
\text { exposed }\end{array}$} & \multicolumn{2}{|c|}{ All employees } \\
\hline & & $O$ & $E$ & $O$ & $E$ & $O$ & $E$ & $O$ & $E$ & $O$ & $E$ \\
\hline $\begin{array}{l}\text { Total deaths } \\
\text { Tumours }\end{array}$ & & 139 & $145 \cdot 3$ & 138 & $127 \cdot 3$ & 56 & $67 \cdot 3$ & 47 & $42 \cdot 4$ & 380 & $382 \cdot 3$ \\
\hline $\begin{array}{l}\text { ICD } 140-239 \\
\text { Circulatory diseases }\end{array}$ & & 23 & $28 \cdot 1$ & 19 & $25 \cdot 8$ & 18 & $13 \cdot 6$ & 9 & $9 \cdot 2$ & 69 & $76 \cdot 7$ \\
\hline $\begin{array}{l}\text { ICD } 390-458 \\
\text { Respiratory diseases }\end{array}$ & & 75 & 65.9 & 65 & 59.9 & 22 & $30 \cdot 8$ & 20 & $17 \cdot 8$ & 182 & $174 \cdot 4$ \\
\hline $\begin{array}{l}\text { ICD 460-519 } \\
\text { Digestive diseases }\end{array}$ & & 5 & $8 \cdot 4$ & 9 & $7 \cdot 1$ & 1 & $3 \cdot 7$ & 1 & $1 \cdot 9$ & 16 & $21 \cdot 1$ \\
\hline $\begin{array}{l}\text { ICD } 520-577 \\
\text { Urogenital diseases }\end{array}$ & & 9 & $6 \cdot 3$ & 11 & $5 \cdot 7$ & 2 & $3 \cdot 0$ & 2 & $2 \cdot 0$ & 24 & $17 \cdot 0$ \\
\hline $\begin{array}{l}\text { ICD 580-629 } \\
\text { Accidents, poisoning, and violence }\end{array}$ & & 3 & $4 \cdot 6$ & 5 & 3.9 & 1 & $2 \cdot 1$ & 2 & $1 \cdot 1$ & 11 & $11 \cdot 7$ \\
\hline $\begin{array}{l}\text { ICD 800-999 } \\
\text { Other causes }\end{array}$ & & $\begin{array}{l}13 \\
11\end{array}$ & $\begin{array}{l}11 \cdot 0 \\
21 \cdot 0^{*}\end{array}$ & $\begin{array}{r}21 \\
8\end{array}$ & $\begin{array}{l}9 \cdot 9 \dagger \\
15 \cdot 0\end{array}$ & $\begin{array}{l}8 \\
4\end{array}$ & $\begin{array}{c}10 \cdot 3 \\
3 \cdot 8\end{array}$ & $\begin{array}{l}6 \\
7\end{array}$ & $\begin{array}{l}4 \cdot 7 \\
5 \cdot 7\end{array}$ & $\begin{array}{l}48 \\
30\end{array}$ & $\begin{array}{c}35 \cdot 9 \\
45 \cdot 5 \ddagger\end{array}$ \\
\hline $\begin{array}{l}\text { No of workers } \\
\text { No of man years }\end{array}$ & & & 841 & & $\begin{array}{l}558 \\
344\end{array}$ & & $\begin{array}{r}326 \\
5152\end{array}$ & & $\begin{array}{r}351 \\
4891\end{array}$ & & $\begin{array}{r}1876 \\
28688\end{array}$ \\
\hline
\end{tabular}

${ }^{*} p=0.023 . \quad \nmid p=0.0027 . \quad \ddagger p=0.016 . \quad O=$ observed. $\quad E=$ expected. 
Table 4 Different types of tumours among workers at different working sites during 1951-75

\begin{tabular}{|c|c|c|c|c|c|c|c|c|c|c|}
\hline \multirow[t]{2}{*}{$I C D$ site No } & \multicolumn{2}{|c|}{ Arc-furnaces } & \multicolumn{2}{|c|}{$\begin{array}{l}\text { Transport, metal } \\
\text { grinder, sampling }\end{array}$} & \multicolumn{2}{|c|}{ Maintenance } & \multicolumn{2}{|c|}{$\begin{array}{l}\text { Office, storage } \\
\text { area, other } \\
\text { non-chromium } \\
\text { exposed }\end{array}$} & \multicolumn{2}{|c|}{ All employees } \\
\hline & $O$ & $\boldsymbol{E}$ & $O$ & $E$ & $O$ & $\boldsymbol{E}$ & $O$ & $E$ & $O$ & $\boldsymbol{E}$ \\
\hline $\begin{array}{l}\text { 140-239 Tumours, all sites } \\
151 \text { Stomach } \\
152+153 \text { Small intestine and colon } \\
155 \text { Rectum } \\
162+163 \text { Trachea, bronchus, lung, pleura } \\
185 \text { Prostate } \\
204-207 \text { Leukaemia } \\
\text { Other locations }\end{array}$ & $\begin{array}{r}23 \\
4 \\
2 \\
0 \\
1 \\
2 \\
1 \\
13\end{array}$ & $\begin{array}{r}28 \cdot 1 \\
5 \cdot 1 \\
2 \cdot 4 \\
1 \cdot 5 \\
2 \cdot 4 \\
4 \cdot 0 \\
1 \cdot 2 \\
11 \cdot 5\end{array}$ & $\begin{array}{r}19 \\
6 \\
0 \\
2 \\
0 \\
4 \\
1 \\
6\end{array}$ & $\begin{array}{r}25 \cdot 8 \\
4 \cdot 6 \\
2 \cdot 1 \\
1 \cdot 3 \\
2 \cdot 5 \\
3 \cdot 4 \\
1 \cdot 0 \\
10 \cdot 9\end{array}$ & $\begin{array}{r}18 \\
1 \\
1 \\
0 \\
3 \\
4 \\
0 \\
9\end{array}$ & $\begin{array}{r}13.6 \\
2.4 \\
1.1 \\
0.7 \\
1.3 \\
1.9 \\
0.6 \\
5.6\end{array}$ & $\begin{array}{l}9 \\
3 \\
1 \\
0 \\
1 \\
2 \\
1 \\
1\end{array}$ & $\begin{array}{l}9.2 \\
1.5 \\
0.8 \\
0.5 \\
1.0 \\
0.6 \\
0.4 \\
4.4\end{array}$ & $\begin{array}{r}69 \\
14 \\
4 \\
2 \\
5 \\
12 \\
3 \\
29\end{array}$ & $\begin{array}{r}76.7 \\
13.6 \\
6.4 \\
4.0 \\
7.2 \\
9.9 \\
3.2 \\
32.4\end{array}$ \\
\hline $\begin{array}{l}\text { No of workers } \\
\text { No of man years }\end{array}$ & \multicolumn{2}{|c|}{$\begin{array}{r}641 \\
9301\end{array}$} & \multicolumn{2}{|c|}{$\begin{array}{r}558 \\
9344\end{array}$} & \multicolumn{2}{|c|}{$\begin{array}{r}326 \\
5152\end{array}$} & \multicolumn{2}{|c|}{$\begin{array}{r}351 \\
4891\end{array}$} & \multicolumn{2}{|c|}{$\begin{array}{r}1876 \\
28688\end{array}$} \\
\hline
\end{tabular}

Table 5 Deaths from tumours of different sites for different length of employment during 1951-75

\begin{tabular}{|c|c|c|c|c|c|c|c|c|c|}
\hline \multirow[t]{3}{*}{$I C D N o$} & \multirow[t]{3}{*}{ Cause of death } & \multicolumn{6}{|c|}{ Length of employment in years } & \multirow{2}{*}{\multicolumn{2}{|c|}{ Total }} \\
\hline & & \multicolumn{2}{|l|}{$1-4$} & \multicolumn{2}{|c|}{$5-14$} & \multicolumn{2}{|c|}{$\geqslant 15$} & & \\
\hline & & $O$ & $\boldsymbol{E}$ & $O$ & $\boldsymbol{E}$ & $O$ & $\boldsymbol{E}$ & $O$ & $E$ \\
\hline $\begin{array}{l}140-239 \\
151 \\
152+153 \\
154 \\
162+163 \\
185 \\
204-207\end{array}$ & $\begin{array}{l}\text { Tumours, all sites } \\
\text { Stomach } \\
\text { Small intestine and colon } \\
\text { Rectum } \\
\text { Trachea, bronchus, lung, pleura } \\
\text { Prostate } \\
\text { Leukaemia } \\
\text { Other locations }\end{array}$ & $\begin{array}{r}16 \\
5 \\
1 \\
1 \\
1 \\
3 \\
0 \\
5\end{array}$ & $\begin{array}{r}16 \cdot 1 \\
2 \cdot 5 \\
1 \cdot 3 \\
0 \cdot 7 \\
1 \cdot 7 \\
1 \cdot 3 \\
0 \cdot 8 \\
7 \cdot 8\end{array}$ & $\begin{array}{r}21 \\
6 \\
1 \\
1 \\
1 \\
2 \\
0 \\
10\end{array}$ & $\begin{array}{r}21 \cdot 5 \\
3 \cdot 7 \\
1 \cdot 8 \\
1 \cdot 2 \\
2 \cdot 3 \\
2 \cdot 5 \\
1 \cdot 0 \\
9 \cdot 0\end{array}$ & $\begin{array}{r}32 \\
3 \\
2 \\
0 \\
3 \\
7 \\
3 \\
14\end{array}$ & $\begin{array}{r}39 \cdot 1 \\
7 \cdot 4 \\
3 \cdot 3 \\
2 \cdot 1 \\
3 \cdot 2 \\
6 \cdot 4 \\
1 \cdot 4 \\
15 \cdot 3\end{array}$ & $\begin{array}{r}69 \\
14 \\
4 \\
2 \\
5 \\
12 \\
3 \\
29\end{array}$ & $\begin{array}{r}76 \cdot 7 \\
13 \cdot 6 \\
6 \cdot 4 \\
4 \cdot 0 \\
7 \cdot 2 \\
10 \cdot 2 \\
3 \cdot 2 \\
32 \cdot 1\end{array}$ \\
\hline $\begin{array}{l}\text { No of workers } \\
\text { No of man years }\end{array}$ & & \multicolumn{2}{|c|}{$\begin{array}{r}783 \\
9530\end{array}$} & \multicolumn{2}{|c|}{$\begin{array}{r}549 \\
8272\end{array}$} & \multicolumn{2}{|c|}{$\begin{array}{r}544 \\
10886\end{array}$} & \multicolumn{2}{|c|}{$\begin{array}{r}1876 \\
28688\end{array}$} \\
\hline
\end{tabular}

Table 6 Deaths from tumours for different work places and for different lengths of employment during 1951-75

\begin{tabular}{|c|c|c|c|c|c|c|c|c|}
\hline \multirow[t]{3}{*}{ Work place } & \multicolumn{6}{|c|}{ Length of employment in years } & \multirow{2}{*}{\multicolumn{2}{|c|}{ Total }} \\
\hline & \multicolumn{2}{|c|}{$1-4$} & \multicolumn{2}{|c|}{$5-14$} & \multicolumn{2}{|c|}{$\geqslant 15$} & & \\
\hline & $O$ & $\boldsymbol{E}$ & $o$ & $E$ & $O$ & $E$ & $O$ & $E$ \\
\hline $\begin{array}{l}\text { Arc-furnaces }(n=641,9301 \text { man years) } \\
\text { Transport, metal grinder, sampling }(n=558,9344 \text { man years) } \\
\text { Maintenance }(n=326,5152 \text { man years) } \\
\text { Office, storage area, other non-chromium exposed }(n=351,4891 \text { man years) }\end{array}$ & $\begin{array}{l}3 \\
7 \\
4 \\
2\end{array}$ & $\begin{array}{l}5 \cdot 0 \\
7 \cdot 3 \\
2 \cdot 1 \\
1 \cdot 7\end{array}$ & $\begin{array}{l}7 \\
5 \\
7 \\
2\end{array}$ & $\begin{array}{l}7 \cdot 8 \\
8 \cdot 3 \\
3 \cdot 0 \\
2 \cdot 4\end{array}$ & $\begin{array}{r}13 \\
7 \\
7 \\
5\end{array}$ & $\begin{array}{r}15 \cdot 3 \\
10 \cdot 2 \\
8 \cdot 5 \\
5 \cdot 1\end{array}$ & $\begin{array}{r}23 \\
19 \\
18 \\
9\end{array}$ & $\begin{array}{r}28 \cdot 1 \\
25 \cdot 8 \\
13 \cdot 6 \\
9 \cdot 2\end{array}$ \\
\hline
\end{tabular}

The number of deaths from respiratory tumours and all tumours for the whole group are shown in table 7. Data were obtained from local parish death registers. During 1931-50, 14 deaths occurred from tumours and during 1951-75 the number was 66. Respiratory tumours made up $43 \%$ of the total during the first period, and $14 \%$ during the second.

\section{INCIDENCE OF CANCER}

The incidence of tumours among the workers, related to length of employment, is shown in table 8. The only significant difference found was in the incidence of cancer in the stomach, which was less than expected. When considering the effect of place of work, a significantly higher incidence of respiratory tumours was found among maintenance workers (table 9). Further analysis of the four cases of lung cancer in this group of workers showed that two were diagnosed as pleural mesotheliomas (table 10). Three of the four had worked at the plant during 1934-41; the time between first employment and date of diagnosis varied from 28 to 37 years.

One of the cases of respiratory cancer in the arcfurnace group was also diagnosed as a mesothelioma. He had worked from 1935 to 1946. 
Table 7 Deaths from all tumours and respiratory tumours during two time periods (diagnoses from parish death registers)

\begin{tabular}{lcccccc}
\hline Year of death & $\begin{array}{l}\text { No of } \\
\text { deaths }\end{array}$ & \multicolumn{2}{l}{$\begin{array}{l}\text { Respiratory } \\
\text { tumours }\end{array}$} & \multicolumn{2}{l}{ All } & \multicolumn{2}{l}{$\begin{array}{l}\text { tumours } \\
\text { No Respira- }\end{array}$} \\
& & No & $\%$ & No & $\%$ & $\begin{array}{l}\text { tory } \\
\text { tumours of } \\
\text { all tumours }\end{array}$ \\
\hline $1931-50$ & 56 & 6 & 11 & 14 & 25 & 43 \\
$1951-75$ & 380 & 9 & 2 & 66 & 17 & 14 \\
\hline
\end{tabular}

\section{Discussion}

The information on the levels of chromium exposure in different parts of the industry was based on approximations, and no measured data existed for the period when a possible occupational cancer could have been induced. General working conditions, however, are known to have improved considerably over the past decade. It seems reasonable to use the results from the mortality study to evaluate the risk present today, even in the absence of accurate exposure data. The estimated exposure data should not be used to construct general doseresponse relationships or to define threshold values.

The results of the investigation illustrate the necessity to relate mortality and incidence of cancer data in a study group to data from a reference population that is geographically as close as possible to the one being investigated. In this study county mortality data were used. If the mortality data for the whole country had been used, ${ }^{3}$ the expected value for respiratory tumours would have been 11 instead of 7.2 and an actual increase of four cases would have been masked.

If agents present in the working environment cause cancer a certain latency period is necessary before the disease appears. By allowing for a

Table 8 Number of cases of tumours of different sites for different lengths of employment during 1958-75

\begin{tabular}{|c|c|c|c|c|c|c|c|c|}
\hline \multirow[t]{2}{*}{ ICD site $N o$} & \multicolumn{6}{|c|}{ Length of employment in years } & \multirow{2}{*}{\multicolumn{2}{|c|}{ Total }} \\
\hline & \multicolumn{2}{|l|}{$1-4$} & \multicolumn{2}{|c|}{$5-14$} & \multicolumn{2}{|c|}{$\geqslant 15$} & & \\
\hline $\begin{array}{l}151 \text { Stomach } \\
153 \text { Colon } \\
155 \text { Liver } \\
157 \text { Pancreas } \\
162+163 \text { Trachea, bronchus, lung and pleura } \\
185 \text { Prostate } \\
189 \text { Kidney } \\
203 \text { Multiple myeloma } \\
\text { Other locations } \\
\text { All sites }\end{array}$ & $\begin{array}{r}3 \\
1 \\
1 \\
0 \\
1 \\
5 \\
2 \\
0 \\
5 \\
18\end{array}$ & $\begin{array}{r}1 \cdot 7 \\
1 \cdot 3 \\
0 \cdot 3 \\
0 \cdot 6 \\
1 \cdot 4 \\
2 \cdot 8 \\
0 \cdot 9 \\
0 \cdot 3 \\
7 \cdot 3 \\
16 \cdot 6\end{array}$ & $\begin{array}{r}2 \\
2 \\
0 \\
1 \\
4 \\
4 \\
2 \\
0 \\
5 \\
20\end{array}$ & $\begin{array}{r}2 \cdot 6 \\
1 \cdot 8 \\
0 \cdot 4 \\
0 \cdot 8 \\
1 \cdot 6 \\
4 \cdot 6 \\
1 \cdot 0 \\
0 \cdot 4 \\
8 \cdot 3 \\
21 \cdot 5\end{array}$ & $\begin{array}{r}1 \\
4 \\
2 \\
1 \\
2 \\
14 \\
1 \\
4 \\
20 \\
49\end{array}$ & $\begin{array}{r}6.3 * \\
4 \cdot 2 \\
1.0 \\
1.6 \\
2.9 \\
11 \cdot 7 \\
2.1 \\
1.0 \\
17 \cdot 0 \\
47 \cdot 8\end{array}$ & $\begin{array}{r}6 \\
7 \\
3 \\
2 \\
7 \\
23 \\
5 \\
4 \\
30 \\
87\end{array}$ & $\begin{array}{r}10 \cdot 6 \\
7 \cdot 3 \\
1 \cdot 7 \\
3 \cdot 0 \\
5 \cdot 9 \\
19 \cdot 1 \\
4 \cdot 0 \\
1 \cdot 7 \\
32 \cdot 6 \\
85.9\end{array}$ \\
\hline $\begin{array}{l}\text { No of workers } \\
\text { No of man years }\end{array}$ & \multicolumn{2}{|c|}{$\begin{array}{r}768 \\
3988\end{array}$} & \multicolumn{2}{|c|}{$\begin{array}{r}538 \\
2976\end{array}$} & \multicolumn{2}{|c|}{$\begin{array}{r}517 \\
5427\end{array}$} & \multicolumn{2}{|c|}{$\begin{array}{r}1823 \\
12391\end{array}$} \\
\hline
\end{tabular}

$* \mathrm{p}=0.013$.

Table 9 Number of cases of tumours of different sites for different work places during 1958-75

\begin{tabular}{|c|c|c|c|c|c|c|c|c|}
\hline \multirow[t]{2}{*}{$I C D$ site No } & \multicolumn{2}{|c|}{ Arc-furnaces } & \multicolumn{2}{|c|}{ Maintenance } & \multicolumn{2}{|c|}{$\begin{array}{l}\text { Transport, metal } \\
\text { grinding, sampling }\end{array}$} & \multicolumn{2}{|c|}{$\begin{array}{l}\text { Office, storage area, } \\
\text { other non-chromium } \\
\text { exposed }\end{array}$} \\
\hline & $O$ & $E$ & $O$ & $E$ & $O$ & $E$ & $O$ & $E$ \\
\hline $\begin{array}{l}151 \text { Stomach } \\
153 \text { Colon } \\
155 \text { Liver } \\
157 \text { Pancreas } \\
162+163 \text { Trachea, bronchus, lung, and pleura } \\
185 \text { Prostate } \\
189 \text { Kidney } \\
203 \text { Multiple myeloma } \\
\text { Other locations } \\
\text { All sites }\end{array}$ & $\begin{array}{r}1 \\
3 \\
0 \\
2 \\
2 \\
5 \\
3 \\
2 \\
13 \\
31\end{array}$ & $\begin{array}{r}3 \cdot 9 \\
2 \cdot 6 \\
0 \cdot 6 \\
1 \cdot 1 \\
2 \cdot 1 \\
7 \cdot 1 \\
1 \cdot 4 \\
0 \cdot 6 \\
11 \cdot 4 \\
30 \cdot 8\end{array}$ & $\begin{array}{r}0 \\
1 \\
1 \\
0 \\
4 \\
7 \\
1 \\
1 \\
4 \\
19\end{array}$ & $\begin{array}{l}2 \cdot 0 \\
1 \cdot 3 \\
0 \cdot 3 \\
0 \cdot 6 \\
1 \cdot 0^{*} \\
3 \cdot 6 \\
0 \cdot 7 \\
0 \cdot 3 \\
5 \cdot 8 \\
15 \cdot 6\end{array}$ & $\begin{array}{r}3 \\
3 \\
2 \\
0 \\
0 \\
7 \\
1 \\
1 \\
9 \\
26\end{array}$ & $\begin{array}{r}3.7 \\
2.5 \\
0.6 \\
1.0 \\
2.1 \\
6.6 \\
1.4 \\
0.6 \\
11.5 \\
30.0\end{array}$ & $\begin{array}{r}2 \\
0 \\
0 \\
0 \\
1 \\
4 \\
0 \\
0 \\
4 \\
11\end{array}$ & $\begin{array}{l}1 \cdot 1 \\
0.8 \\
0.2 \\
0.3 \\
0.7 \\
1 \cdot 8 \\
0.5 \\
0.2 \\
3.9 \\
9 \cdot 5\end{array}$ \\
\hline $\begin{array}{l}\text { No of workers } \\
\text { No of man years }\end{array}$ & \multicolumn{2}{|c|}{$\begin{array}{r}622 \\
3955 \cdot 5\end{array}$} & \multicolumn{2}{|c|}{$\begin{array}{r}315 \\
2512\end{array}$} & \multicolumn{2}{|c|}{$\begin{array}{r}543 \\
4206 \cdot 5\end{array}$} & \multicolumn{2}{|c|}{$\begin{array}{r}343 \\
1717\end{array}$} \\
\hline
\end{tabular}

$p=0.038$ 
Table 10 Employment time, age, and year of diagnosis among maintenance workers with respiratory tumours

\begin{tabular}{llll}
\hline $\begin{array}{l}\text { Period of } \\
\text { employment }\end{array}$ & $\begin{array}{l}\text { Year of } \\
\text { diagnosis }\end{array}$ & $\begin{array}{l}\text { Age at } \\
\text { diagnosis }\end{array}$ & $\begin{array}{l}\text { Time between } \\
\text { first employment } \\
\text { year and year of } \\
\text { diagnosis }\end{array}$ \\
\hline $1934-37$ & 1965 & 60 & 31 \\
$1935-40^{*}$ & 1972 & 71 & 37 \\
$1935-41$ & 1963 & 54 & 28 \\
$1935-69^{*}$ & 1969 & 62 & 34 \\
\hline
\end{tabular}

* Pleural mesothelioma.

latency period in a study of this type, individuals who have contracted the disease only a short time after starting work are not included in the evaluation. The precision of the anaylsis in relating a disease to the working environment thus increases.

The latent period varies for different exposures and for different tumours ${ }^{5-7}$ and is not known for several types of tumours. The choice of 15 years as a latent period for all cancer sites in this investigation must therefore be considered as approximate.

Cases of cancer were not more frequent among those employed in the plant than in the county population and no increase was found in the rate of respiratory tumours among the highly exposed workers at the arc-furnaces. Langård and his co-workers have conducted a similar study in a ferrochromium plant in Norway in which seven cases of lung cancer were found among the population working at ferrochromium arc-furnaces compared with an expected number of $3 \cdot 1$.

The occurrence of perforations of the nasal septum in both the Norwegian and Swedish workers indicated that hexavalent chromium has been present in the past. Possible variations in exposure to this agent may account for the difference in the death rate from lung cancer found in the two studies. The $95 \%$ confidence interval does not exclude a relative risk of 2.5 in the Swedish study.

The results from this study and that of Langård et $a l^{8}$ do not support the suggestion by Mancuso in Toronto in 1975 that trivalent chromium compounds may be as carcinogenic as chromates. Mancuso analysed the death rate from lung cancer in a chromate manufacturing plant. Among 41 observed cases a dose-response relationship could be observed for exposure to soluble chromium compounds. A similar dose-response relationship was shown for exposure to total chromium. In his analysis Mancuso subdivided the cohort in different categories of exposure to total insoluble chromium. These classes were then divided into categories with varying degrees of exposure to total chromium. The incidence of lung cancer rose with an increase in the level of exposure to total chromium in four out of five of these classes.

Mancuso concluded that the risk of lung cancer is a function of exposure to total chromium rather than to one class of chromium compounds, but the analysis is incomplete as no statistical treatment of the data was presented. Moreover, the fact that the insoluble chromium compounds could have been chromates and not only trivalent chromium, and that all cases had been exposed to soluble chromium, makes the conclusions doubtful.

In the present study no information about smoking habits among the employed was available. Rapaport ${ }^{9}$ showed that smoking habits differ among populations in rural and urban areas but that there was no excess in smoking among industry workers. The plant in the present investigation was in a town, and most of the reference county was a rural area. Thus it cannot be excluded that differences in smoking patterns existed between the general population and the workers in the industry. According to calculations by Axelson ${ }^{10}$ the rate of lung cancer would be about $20 \%$ higher than expected if the proportion of heavy smokers in an industrial population is $15 \%$ compared to $10 \%$ in the reference population. In this study such differences would have increased the expected number of respiratory tumours from 5.9 to $7 \cdot 1$. Data from the previously cited study on smoking in Sweden, however, indicate that the difference in smoking habits between towns and rural areas is not of that magnitude.

The presence of mesotheliomas among workers can probably be related to the handling of asbestos, which occurred at the time when these cases were induced. Probably this exposure could also be responsible for some of the other cases of respiratory cancer.

The significance of the difference seen in the proportion of deaths from respiratory tumours between the periods 1931-50 and 1951-75 cannot be evaluated with certainty as it was not possible to calculate an expected value for the earlier period. Of the six men who died from respiratory tumours before 1951 two worked at the furnaces, one in the transport group, one in the maintenance group, and two in the office.

A slight increase in incidence of prostatic cancer was seen in the maintenance group. Among maintenance personnel fewer than expected died during 1951-75. The average age of this group was thus higher than in the reference population. The risk for contracting prostatic cancer increases considerably after 75 years of age, and three of the seven cases were more than 80 when the diagnosis was made. Data from the Swedish Cancer Registry ${ }^{4}$ show that 
the incidence in prostatic cancer in these age groups is very dependent on the necropsy rate and it is, therefore, not possible to relate the increase to any particular exposure in the plant.

A greater number of suicides and drownings was noted among the industrial workers, compared with the county population. It was most pronounced among those who had been employed for only a short time, and especially in the transport group. Excessive alcohol consumption was indicated on some of the death certificates in this group.

In conclusion, this study could not show an increased death rate or an increase in the incidence of cancer in the ferrochromium plant population. It is therefore reasonable to believe that the risk of developing respiratory tumours after inhaling trivalent chromium compounds is considerably less than the risk of developing such tumours after exposure to chromates.

\section{References}

${ }^{1}$ Enterline PE. Respiratory cancer among chromate workers. J Occup Med 1974;16:523-6.
${ }^{2}$ Langård S, Norseth T. A cohort study of bronchial carcinomas in workers producing chromate pigments. Br J Ind Med 1975;32:62-5.

${ }^{3}$ National Central Bureau of Statistics. Causes of death 195175. Stockholm: 1954-77.

4 National Board of Health and Welfare. Cancer incidence in Sweden 1958-72. Stockholm: Cancer Registry, 1960:77.

5 Armenian HK, Lilienfeld AM. The distribution of incubation periods of neoplastic diseases. Am J Epidemiol $1974 ; 09: 92-100$.

- Selikoff IJ, Hammond EC. Community effects of nonoccupational environmental asbestos exposure. Am J Public Health 1968; 58:1658-66.

${ }^{7}$ Enterline PE. Pitfalls in epidemiological research. $J$ Occup Med 1976;18:150-6.

${ }^{3}$ Langård S, Andersen Aa, Gylseth B. Cancer incidence among ferrochromium and ferrosilicon workers. $\mathrm{Br}$ $J$ Ind Med 1980;37:114-20.

- Rapaport E. Smoking habits in Sweden. A postal survey in spring 1963. Stockholm: National Central Bureau of Statistics, 1965. (In Swedish.)

${ }^{10}$ Axelson O. Aspects on confounding in occupational health epidemiology. Scand J Work, Environ Health $1978 ; 4: 98-102$. 